\title{
Potassium Dichromate as a Reference Substance for Embryonic Tests of Toxicity in the Common Carp (Cyprinus carpio L.)
}

\author{
R. KREJČÍ ${ }^{1}$, M. PALÍKOVÁ2 \\ ${ }^{1}$ Department of Zoology, Fisheries, Hydrobiology and Apiculture, Mendel's Agricultural and Forestry \\ University in Brno, Czech Republic \\ ${ }^{2}$ Department of Veterinary Ecology and Environmental Protection, University of Veterinary and Pharmaceutical \\ Sciences, Brno, Czech Republic \\ Received September 29, 2005 \\ Accepted March 16, 2006
}

\begin{abstract}
Krejčí R., M. Palíková: Potassium Dichromate as a Reference Substance for Embryonic Tests of Toxicity in the Common Carp (Cyprinus carpio L.). Acta Vet. Brno, 75: 259-263.

Potassium dichromate $\left(\mathrm{K}_{2} \mathrm{Cr}_{2} \mathrm{O}_{7}\right)$ has already been used as a reference substance in tests of toxicity with aquatic animals. The aim of this study was to determine and compare values of $\mathrm{LC}_{50}$ for potassium dichromate during the whole period of embryonic development (i.e., $120 \mathrm{~h}$ ) and $48 \mathrm{~h}$ after hatching of embryos in the common carp (Cyprinus carpio L.). Fish eggs and embryos were exposed to 5 different concentrations of potassium dichromate (i.e., 372, 409, 450, 495, 545 $\mathrm{mg} \cdot \mathrm{l}^{-1}$ ) during two experiments. Such characteristics as the cumulative mortality, the start and the end of hatching, the number of deformities, body length, and body mass of surviving individuals were studied during the tests. The highest mortality was found in the hatched embryos. Mortality and frequency of deformities increased with the growing concentration of potassium dichromate. The value of $120 \mathrm{LC}_{50}$ for potassium dichromate was $464.91 \pm 23.83 \mathrm{mg} \cdot \mathrm{l}^{-1}$ and the value of $48 \mathrm{LC}_{50}$ was $458.94 \pm 4.14 \mathrm{mg} \cdot \mathrm{l}^{-1}$ (mean $\pm \mathrm{SD}$ ). No statistically significant difference between values 120 $\mathrm{LC}_{50}$ a $48 \mathrm{LC}_{50}$ was found. This is why reduction of the exposure period to only $48 \mathrm{~h}$ after hatching seems a reasonable method to study the control of susceptibility using potassium dichromate in embryonic tests of toxicity.
\end{abstract}

Lethal concentration, embryonic toxicity, mortality, deformations, hatching

The toxicity of chemical substances for aquatic organisms may be influenced by a variety of factors such as the physical and chemical characteristics of water (e.g., temperature, $\mathrm{pH}$, oxygen concentration, concentrations of salts dissolved in water, etc.) and the state of health of the animals tested. Although it is possible to create standard laboratory conditions, maintaining indicators of the state of health as well as susceptibility may be more problematic. That is why toxicity tests employing reference substances are used in ecotoxicology. Results of these tests enable comparisons with those obtained by testing various substances on fish of different origin. Potassium dichromate $\left(\mathrm{K}_{2} \mathrm{Cr}_{2} \mathrm{O}_{7}\right)$ is the most commonly used and recommended reference substance for aquatic organisms (CSN EN ISO 6341, 1996 and ČSN EN ISO 7346, 1996).

The effect of chromium on the fish organism has already been studied in detail. Studies were particularly focused on the hexavalent chromium that is more toxic to aquatic organisms than chromium with the valency of III (Van der Putte et al. 1981ab). Effects of chromium on fish are reported to include damage of gills, impairment of osmoregulation, blood count changes, etc. (Al-Akel et al. 1996; Nath et al. 1988; Van der Putte et al. 1982). Chromium $\mathrm{Cr}^{\mathrm{VI}}$ is more toxic at a lower $\mathrm{pH}$, like other metals (S to u th art et al.1996). Significantly higher levels of chromium were found in the epithelium of gills in the rainbow trout kept at the $\mathrm{pH}$ of 6.5 as compared to the $\mathrm{pH}$ of 7.8 (V an der Putte et al. 1981ab). In eggs and larvae of the common carp, Stouthart et al. (1995) also found the mortality as well as the accumulation of chromium to be the significantly highest at the $\mathrm{pH}$ of 6.3 . These

Address for correspondence:

Ing. Roman Krejčí, Ph.D.

Department of Zoology, Fisheries, Hydrobiology and Apiculture

Mendel's Agricultural and Forestry University in Brno

Zemědělská 1, 61300 Brno, Czech Republic

Phone: +420545133267

E-mail:krejca@mendelu.cz

http://www.vfu.cz/acta-vet/actavet.htm 
authors also found that the chorion and the perivitelline membrane of eggs acts like an effective barrier against $\mathrm{Cr}^{\mathrm{VI}}$ and that after hatching the accumulation of $\mathrm{Cr}^{\mathrm{VI}}$ in embryos and larvae starts to grow. In spite of that, there are no published data on the medium lethal dose for fish eggs and sac-fry of the common carp.

This paper is aimed at finding and comparing the $\mathrm{LC}_{50}$ values for potassium dichromate and the whole embryonic development $(120 \mathrm{~h})$ as well as the period of $48 \mathrm{~h}$ after hatching.

\section{Materials and Methods}

Two experiments were performed in order to evaluate the influence of different concentrations of potassium dichromate during the embryonic development in the common carp. Experiments were carried out to determine the influence of potassium dichromate during the whole embryonic development, i.e., from fertilization to the end of the embryonic period, and during $48 \mathrm{~h}$ after hatching, i.e., from hatching to the end of the embryonic development. Experiments were finished when control individuals had the gas bladders filled and were able to take feed. Fish eggs and embryos were subjected to the same concentrations of potassium dichromate. Values of $\operatorname{LC}_{50}\left(120 \mathrm{LC}_{50}\right.$ and $48 \mathrm{LC}_{50}$ ) were computed for individual periods of development. Both experiments were performed under the same laboratory conditions and in accordance with the OECD 212 (1998) guideline.

Eggs of the common carp were obtained using artificial spawning and unstuck for one hour by whole milk diluted with water in the ratio of 1:9. Production lines of the common carp were used for stripping (spawner female PL, spawner male M72). Fish eggs were used for the experiment $8 \mathrm{~h}$ after fertilization. Embryos were used just after hatching. Until hatching, fish eggs were incubated in Zugs vials in a re-circulating unit.

Fish eggs and embryos were stocked 15 individuals per $15 \mathrm{ml}$ of water for dilution prepared according to the Czech State Norm ČSN EN ISO 7346 (1996). Water exchange was made using a semi-static method every 12 hours. Fish eggs and embryos were transferred using a fine sieve. Temperature of the medium during the experiment was kept at $23.5 \pm 0.3{ }^{\circ} \mathrm{C}, \mathrm{pH}$ values varied in the range of $6.0 \pm 0.1$, and the $\mathrm{O}_{2}$ concentration ranged from $7.5 \mathrm{to} 8.0 \mathrm{mg} \cdot \mathrm{l}^{-1}$ (90 - 95\% saturation). Photoperiod consisted of $14 \mathrm{~h}$ light and $10 \mathrm{~h}$ dark. The experiments included controls with water for dilution and 5 different concentrations of potassium dichromate (i.e., 372, 409, 450, 495, $545 \mathrm{mg} \cdot \mathrm{l}^{-1}$ ) in three repeated measurements determined by calculation on the basis of $\mathrm{LC}_{50}$ found in preliminary tests.

Characteristics such as cumulative mortality, the onset and the end of hatching, the number of deformities, total body length (TL) and body mass (w) of surviving individuals were determined during the experiments. Body length and mass values of the surviving individuals were determined after 3 months of the specimens being fixed in $4 \%$ formalin.

A computer probit analysis program was used to determine concentrations of potassium dichromate in the experiments as well as the $\mathrm{LC}_{50}$ values. Values of $\mathrm{LC}_{50}$ after 120 and $48 \mathrm{~h}$ were compared using $t$-test in STATplus (Matoušková et al. 1992). As the tests were performed in accordance with the OECD 212 guidelines and under identical conditions, we obtained statistical evaluation of six individual tests of toxicity.

\section{Results}

\section{Cumulative mortality Mortality during $120 \mathrm{~h}$ of exposure (Table 1)}

Table 1. Cumulative mortality (mean \pm SD)

\begin{tabular}{|c|c|c|c|c|}
\hline \multirow{2}{*}{$\begin{array}{c}\text { Concentration } \\
\text { of } \mathrm{K}_{2} \mathrm{Cr}_{2} \mathrm{O}_{7} \\
\left(\mathrm{mg} \cdot \mathrm{l}^{-1}\right)\end{array}$} & $\begin{array}{c}\text { Mortality } \\
\text { within 12 h (\%) }\end{array}$ & $\begin{array}{c}\text { Mortality until the } \\
\text { start of hatching (\%) }\end{array}$ & $\begin{array}{c}\text { Mortality after } \\
120 \mathrm{~h}(\%)\end{array}$ & $\begin{array}{c}\text { Mortality after } \\
48 \mathrm{~h}(\%)\end{array}$ \\
\hline 0 & $2.22 \pm 3.14$ & $3.34 \pm 3.34$ & $3.34 \pm 3.34$ & $0.00 \pm 0.00$ \\
\hline 545 & $3.34 \pm 3.34$ & $3.34 \pm 3.34$ & $93.33 \pm 9.43$ & $100.00 \pm 0.00$ \\
\hline 495 & $4.45 \pm 4.97$ & $4.45 \pm 4.97$ & $71.11 \pm 19.88$ & $84.44 \pm 9.94$ \\
\hline 450 & $1.11 \pm 2.49$ & $1.11 \pm 2.49$ & $35.56 \pm 12.57$ & $33.33 \pm 16.33$ \\
\hline 409 & $3.33 \pm 5.09$ & $3.33 \pm 5.09$ & $21.11 \pm 4.58$ & $5.56 \pm 4.58$ \\
\hline 372 & $3.34 \pm 3.34$ & $3.34 \pm 3.34$ & $12.22 \pm 4.59$ & $3.34 \pm 3.34$ \\
\hline
\end{tabular}

Mortality during the first $12 \mathrm{~h}$ of exposure to potassium dichromate varied from 1.1 to $4.4 \%$. There was no mortality during the period from $12 \mathrm{~h}$ until hatching (except for the control). The highest mortality was found in the period after hatching. It was growing with 
the increasing concentration of potassium dichromate. No increase in mortality was observed in control individuals after hatching.

Mortality during $48 \mathrm{~h}$ of exposure (Table 1 )

There was no mortality in the control groups. Growing concentrations of potassium dichromate resulted in growing mortality of individuals.

\section{Hatching}

Table 2 presents the start and end of hatching in both experiments. In groups exposed to potassium dichromate hatching started from 57.3 to $61.5 \mathrm{~h}$, and was finished from 69.2 to $74.2 \mathrm{~h}$. Hatching started at $62.8 \mathrm{~h}$, and ended at $73 \mathrm{~h}$ in the control group.

\section{Deformities}

The number of deformities varied from 6.7 to $6.8 \%$ in control animals (Table 2). A control animal without deformities is presented in Fig.1 (Plate IX). Deformities of the vertebral

Table 2. Hatching and deformities (mean $\pm \mathrm{SD})$

\begin{tabular}{|c|c|c|c|c|}
\hline $\begin{array}{c}\text { Concentration } \\
\text { of } \mathrm{K}_{2} \mathrm{Cr}_{2} \mathrm{O}_{7} \\
\left(\mathrm{mg} \cdot \mathrm{l}^{-1}\right)\end{array}$ & $\begin{array}{c}\text { Start of hatching } \\
(\mathrm{h})\end{array}$ & $\begin{array}{c}\text { End of hatching } \\
(\mathrm{h})\end{array}$ & $\begin{array}{c}\text { Deformities after } \\
120 \mathrm{~h}(\%)\end{array}$ & $\begin{array}{c}\text { Deformities after } \\
48 \mathrm{~h}(\%)\end{array}$ \\
\hline 0 & $62.83 \pm 1.95$ & $73.00 \pm 2.31$ & $6.83 \pm 5.65$ & $6.67 \pm 5.44$ \\
\hline 545 & $57.33 \pm 2.67$ & $69.67 \pm 4.31$ & $91.67 \pm 11.79$ & - \\
\hline 495 & $57.33 \pm 2.67$ & $70.50 \pm 5.65$ & $88.29 \pm 12.23$ & $90.28 \pm 13.96$ \\
\hline 450 & $57.67 \pm 3.59$ & $69.17 \pm 3.24$ & $63.60 \pm 22.94$ & $52.89 \pm 23.37$ \\
\hline 409 & $59.83 \pm 2.79$ & $71.83 \pm 4.14$ & $45.67 \pm 13.93$ & $33.16 \pm 18.14$ \\
\hline 372 & $61.50 \pm 3.04$ & $74.17 \pm 3.02$ & $33.87 \pm 15.78$ & $18.48 \pm 9.48$ \\
\hline
\end{tabular}

column and yolk sac were most frequent in control groups. The number of deformities was growing with the increasing concentration of potassium dichromate. Deformities of embryos exposed for $120 \mathrm{~h}$ to potassium dichromate included bowing of the vertebral column (Fig. 2), deformities of the head, missing fin margins (Fig. 2), strangulation and enlargement of the yolk sac (Fig. 2 and 3). Swelling of the heart area was very frequent at higher concentrations of potassium dichromate (Fig. 3, Plate X, Fig. 4, 5). Individuals exposed to potassium dichromate for $48 \mathrm{~h}$ showed bowing of the vertebral column less frequently. This duration of exposure resulted most frequently in deformities of the head, yolk sac and swelling of the heart area.

\section{Body length and mass}

Table 3 presents such characteristics as the total body length (TL) and body mass (w) of individuals surviving until the end of the experiment. The total body length and body mass in individuals exposed to different concentrations of potassium dichromate were even lower than in the control animals.

Table 3. Total body length (TL) and mass (w) (mean \pm SD)

\begin{tabular}{|c|c|c|c|c|}
\hline \multirow{2}{*}{$\begin{array}{c}\text { Concentration } \\
\text { of } \begin{array}{c}\mathrm{K}_{2} \mathrm{Cr}_{2} \mathrm{O}_{7} \\
\left(\mathrm{mg} \cdot \mathrm{l}^{-1}\right)\end{array}\end{array}$} & $\begin{array}{c}\mathrm{TL} \\
(\mathrm{mm})\end{array}$ & $\begin{array}{c}\mathrm{W} \\
(\mathrm{mg})\end{array}$ & $\begin{array}{c}\mathrm{TL} \\
(\mathrm{mm})\end{array}$ & $\begin{array}{c}\text { W } \\
(\mathrm{mg})\end{array}$ \\
\hline 0 & $6.16 \pm 0.29$ & $1.63 \pm 0.21$ & $6.38 \pm 0.22$ & $1.60 \pm 0.23$ \\
\hline 545 & $5.31 \pm 0.11$ & $1.12 \pm 0.25$ & - & - \\
\hline 495 & $5.51 \pm 0.34$ & $1.36 \pm 0.22$ & $6.03 \pm 0.32$ & $1.35 \pm 0.33$ \\
\hline 450 & $5.59 \pm 0.24$ & $1.27 \pm 0.06$ & $6.04 \pm 0.32$ & $1.52 \pm 0.27$ \\
\hline 409 & $5.79 \pm 0.14$ & $1.33 \pm 0.09$ & $6.07 \pm 0.21$ & $1.47 \pm 0.11$ \\
\hline 372 & $5.80 \pm 0.15$ & $1.31 \pm 0.10$ & $6.12 \pm 0.28$ & $1.54 \pm 0.16$ \\
\hline
\end{tabular}


$\mathrm{LC}_{50}$ estimate for potassium dichromate

The value of $120 \mathrm{LC}_{50}$ for potassium dichromate was $464.91 \pm 23.83 \mathrm{mg} \cdot \mathrm{l}^{-1}$ (mean $\pm \mathrm{SD}$ ) and the value of $48 \mathrm{LC}_{50}$ was $458.94 \pm 4.14 \mathrm{mg} \cdot \mathrm{l}^{-1}$. No significant difference was found between these values.

\section{Discussion}

Mortality during the first $12 \mathrm{~h}$ of the experiment was probably caused by unfertilized fish eggs or damage through handling during transport.

It is mostly reported that the $\mathrm{LC}_{50}$ value for the hexavalent chromium amounts to $96 \mathrm{~h}$ in fish. According to Benout (1976), the $96 \mathrm{LC}_{50}$ values for the rainbow trout and the brook trout equal to 69 and $59 \mathrm{mg} \mathrm{Cr} \cdot \mathrm{l}^{-1}$, respectively. Al-A kel (1996) mentions the $96 \mathrm{LC}_{50}$ of hexavalent chromium in the common carp to be $93.6 \mathrm{mg} \cdot \mathrm{l}^{-1}$. These authors, however, were not experimenting with embryos, but older age categories. Buhl (1997) reports the $96 \mathrm{LC}_{50}$ value of hexavalent chromium of three species of fish (i.e., colorado squawfish - Ptychocheilus lucius, bonytail - Gila elegans and razorback sucker Xyrauchen texanus) in the range of $32-123 \mathrm{mg} \cdot \mathrm{l}^{-1}$. This author reports the same or higher susceptibility of larvae than juveniles of these species of fish. All these values are many times lower than those found in our study, but they concern a longer time period, i.e., $96 \mathrm{~h}$ as compared to $48 \mathrm{~h}$ of our experiments. It should hold good that the longer the test period, the lower the lethal concentration of the substance. Such results are reported, e.g., by Murti et al. (1983) for chromium and the freshwater prawn - Macrobrachium lamarreia. The $\mathrm{LC}_{50}$ values are $24,48,72$, and $96 \mathrm{~h}$ and show a decreasing tendency of $5.44,3.69,2.47$, and $1.84 \mathrm{mg} \cdot \mathrm{l}^{-1}$, respectively. Comparing the $96 \mathrm{LC}_{50}$ and $48 \mathrm{LC}_{50}$ values, we see that the first one is twice as high as the second. Vykusová and Svobodová (1990) report the range of the $48 \mathrm{LC}_{50}$ values for chromium in the common carp to be $100-350 \mathrm{mg} \cdot \mathrm{l}^{-1}$. Again, these authors were not engaged in embryonic tests, but tests using small fish.

From our results it is clear that the highest mortality in all concentrations of potassium dichromate can be found after hatching, i.e. in the life period when embryos are away from the egg envelopes. This statement has also been confirmed by S to uthart (1995) finding the highest mortality in hatched embryos. The content of $\mathrm{Cr}^{\mathrm{VI}}$ in fish eggs drops nearly to zero levels during hatching and starts to grow in the embryos again after hatching. The higher mortality of the period after hatching can be explained by a barrier formed by the perivitelline membrane of fish eggs, preventing the accumulation of $\mathrm{Cr}^{\mathrm{VI}}$ in embryos. This fact is reflected in values of $\mathrm{LC}_{50}$ determined after 120 and $48 \mathrm{~h}$, which are very similar. Considering the fact that chromium accumulates in the embryos only after hatching, the duration of action of potassium dichromate lasts de facto $48 \mathrm{~h}$ from the total of $120 \mathrm{~h}$ of exposure. The difference between $120 \mathrm{LC}_{50}$ and $48 \mathrm{LC}_{50}$ values amounted to $4.43 \%$ (A) and $6.42 \%(\mathrm{~B})$. The $\mathrm{LC}_{50}$ values differing by up to $10 \%$, however, are considered to be rather the same.

The $120 \mathrm{LC}_{50}$ value may be, due to the susceptibility of embryos to potassium dichromate only after hatching, influenced by this process. The time of hatching may influence the mortality of individuals due to differences in the action of potassium dichromate on hatched embryos. An unusually early or late start of hatching, on the other hand, may also influence mortality and thus the $\mathrm{LC}_{50}$ value.

No statistically significant deference between values $120 \mathrm{LC}_{50}$ and $48 \mathrm{LC}_{50}$ was found. That is why the reduction of the exposure period to only $48 \mathrm{~h}$ after hatching seems a reasonable method to study the control of susceptibility using potassium dichromate in embryonic tests of toxicity. A similar reduction of the exposure to a reference substance (from 96 to $24 \mathrm{~h}$ ) has already been accepted in the Czech State Norm ČSN EN ISO 7346. 


\section{Využití dichromanu draselného jako referenční látky při provádění embryonálních testů toxicity s kaprem obecným (Cyprinus carpio L.)}

Dichroman draselný $\mathrm{K}_{2} \mathrm{Cr}_{2} \mathrm{O}_{7}$ se používá jako referenční látka v testech toxicity s vodními živočichy. Cílem této studie bylo zjistit a porovnat $\mathrm{LC}_{50}$ pro $\mathrm{K}_{2} \mathrm{Cr}_{2} \mathrm{O}_{7}$ za období celého embryonálního vývoje (120 h) a za období 48 h po vykulení embryí u kapra obecného (Cyprinus carpio L.).

Jikry a embrya byly ve dvou pokusech exponovány v 5 koncentracích $\mathrm{K}_{2} \mathrm{Cr}_{2} \mathrm{O}_{7}(372,409$, $\left.450,495,545 \mathrm{mg} \cdot 1^{-1}\right)$. Během testů byla sledována kumulativní mortalita, začátek a konec kulení, počet deformací, celková délka těla a hmotnost přežívajících jedinců. Nejvyšší mortality bylo dosaženo až u vykulených embryí. Mortalita a počet deformací se zvyšovaly se stoupající koncentrací $\mathrm{K}_{2} \mathrm{Cr}_{2} \mathrm{O}_{7}$. Hodnota $120 \mathrm{LC}_{50}$ pro dichroman draselný byla 464.91 $\pm 23.83 \mathrm{mg} \cdot \mathrm{l}^{-1}$ (průměr $\pm \mathrm{SD}$ ) a hodnota $48 \mathrm{LC} 50$ byla $458.94 \pm 4.14 \mathrm{mg} \cdot \mathrm{l}^{-1}$. Statistickým hodnocením nebyl shledán žádný statisticky významný rozdíl mezi hodnotami 120 LC $_{50}$ a 48 LC $_{50}$. Proto se jako vhodná metoda pro kontrolu citlivosti s využitím dichromanu draselného při provádění embryonálních testů toxicity jeví zkrácení expoziční doby na období 48 h po vykulení.

\section{Acknowledgement}

This study was supported by the Research Project of the Ministry of Education, Youth and Sports of the Czech Republic MSM 6215712402 "Veterinary aspects of food safety and quality".

\section{References}

AL-AKEL AS, SHAMSI MJK 1996: Hexavalent chromium: Toxicity and impact on carbohydrate metabolism and haematological parameters of carp (Cyprinus carpio L.) from Saudi Arabia. Aquat Sci 58: 24-30

BUHL KJ 1997: Relative Sensitivity of Three Endangered Fishes, Colorado Squawfish, Bonylail, and Razborback Sucker, to Selected Metal Pollutans. Ecotox and Env Safety 37: 186-192

BENOIT DA 1976: Toxic effects of hexavalent chromium on brook trout (Salvelinus fontinalis) and rainbow trout (Salmo gairdneri). Water Res 10: 497-500

ČSN EN ISO 6341 1996: Determination of the inhibition of the mobility of Daphnia magna Straus (Cladocera, Crustacea - Acute toxicity test. (in Czech) ČNI Praha, 16 p.

ČSN EN ISO 7346-2: 1996. Determination of the lethal toxicity of substances to a freshwater fish (Brachidanio rerio Hamilton- Buchanan (Teleostei, Cyprinidae) - Part 2: Semi-static method. (In Czech) ČNI Praha, 16 pp

MURTI RO, SHUKLA GS 1983: Chromium toxicity to a freshwater prawn Macrobrachium Lamarrei (h.m.edwards). Tox Letters 18: 257-261

MATOUŠKOVÁ O, CHALUPA J, CÍGLER M, HRUŠKA K 1992: Statistic system STAT PLUS, version 1,01. Book of reference. Veterinary Research Institute, Brno, 168 p.

NATH K, KUMAR N 1988: Hexavalent chromium: Toxicity and its impact on certain aspects of carbohydrate metabolism of the freshwater teleost, Colisa fasciatus. Sci of the Total Environ 72: 175-181

OECD guideline for the testing of chemicals 212: Fish, short-term toxicity test on embryo and sac-fry stages, 1998, $20 \mathrm{p}$.

STOUTHART AJHX, SPANINGS FAT, LOCK RAC, BONGA SEW 1995: Effect of water pH on chromium toxicity to early life stages of the common carp (Cyprinus carpio). Aquat Tox 32: 31-42

STOUTHART AJHX, HAANS JLM, LOCK RAC, BONGA SEW 1996: Effect of water pH on copper toxicity to early life stages of the common carp (Cyprinus carpio). Envir Tox. and Chem 15: 376-383

VAN DER PUTTE I, BRINKHORST MA, KOEMAN JH 1981a: Effect of pH on the acute toxicity of hexavalent chromium to rainbow trout (Salmo gairdneri). Aquat Toxicol 1: 129-142

VAN DER PUTTE I, LUBBERS J 1981b: Effect of pH on uptake, tissue distribution and retention of hexavalent chromium in rainbow trout (Salmo gairdneri). Aquat Toxicol 1: 3-18

VAN DER PUTTE I, LAURIER MBHM, VAN EIJK GJM 1982: Respiration and osmoregulation in rainbow trout (Salmo gairdneri) exposed to hexavalent chromium at different $\mathrm{pH}$ values. Aquat Toxicol 2: 99-112

VYKUSOVÁ B, SVOBODOVÁ Z 1990: Acute Toxicity of Standards to Fish. Buletin VÚRH Vodňany (In Czech) 26: $15-20$ 
Plate IX

Krejčí R. et al.: Potassium dichromate ... pp. 259-263

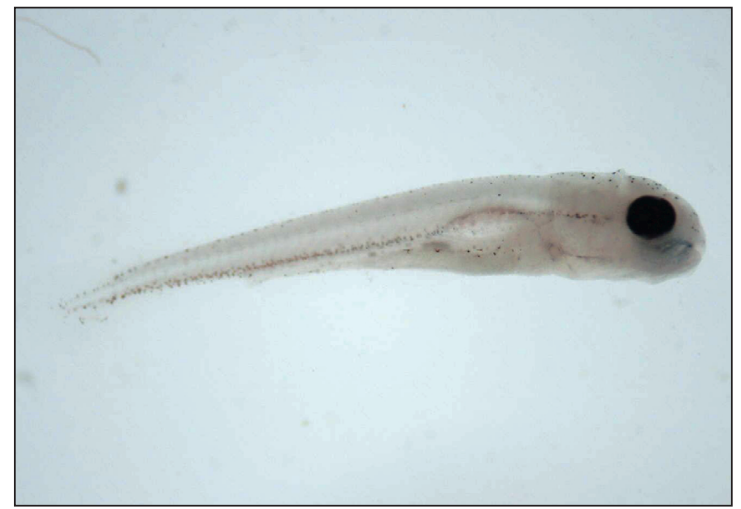

Fig. 1. Control embryo $120 \mathrm{~h}$ old. Magnification $\times 20$; fixed in $4 \%$ formaldehyde.

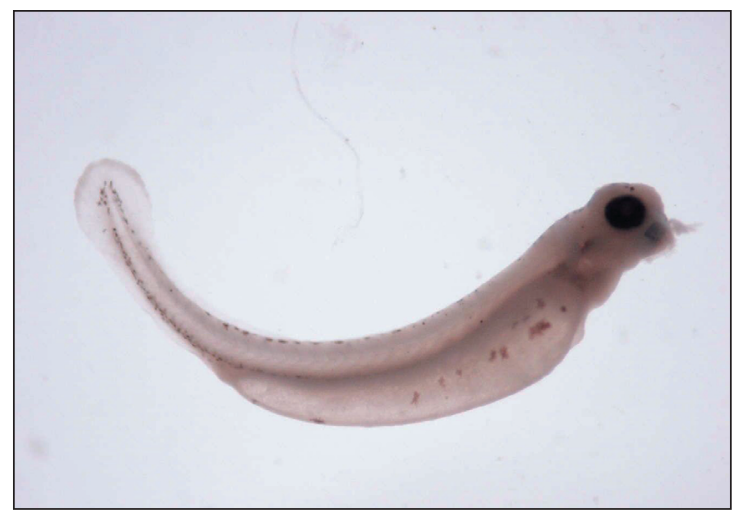

Fig. 2. Embryo (120 h old) exposed to the action of $\mathrm{K}_{2} \mathrm{Cr}_{2} \mathrm{O}_{7}$ at the concentration of $495 \mathrm{mg} \cdot \mathrm{l}^{-1}$. Deformities of the vertebral column (bowing), long yolk sac, absence of fin margins. Magnification $\times 20$; fixed in $4 \%$ formaldehyde

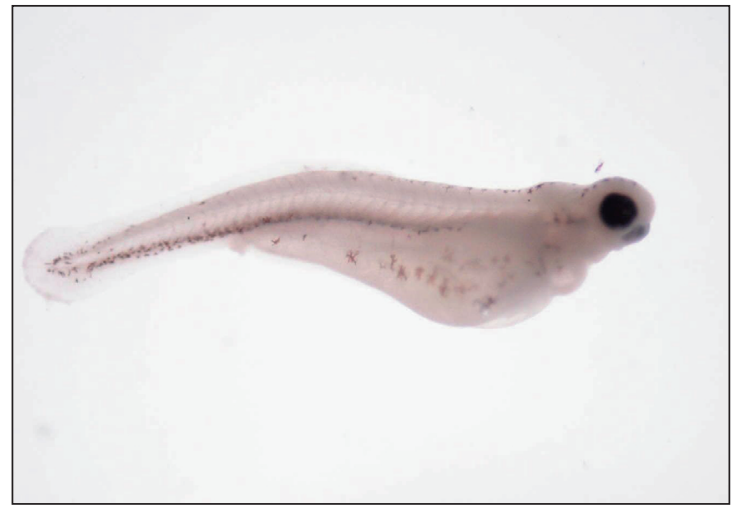

Fig. 3. Embryo (120 h old) exposed to the action of $\mathrm{K}_{2} \mathrm{Cr}_{2} \mathrm{O}_{7}$ at the concentration of $409 \mathrm{mg} \cdot \mathrm{l}^{-1}$. Deformities of yolk sac, head, vertebral column, moderate heart area oedema. Magnification $\times 20$; fixed in $4 \%$ formaldehyde 


\section{Plate X}

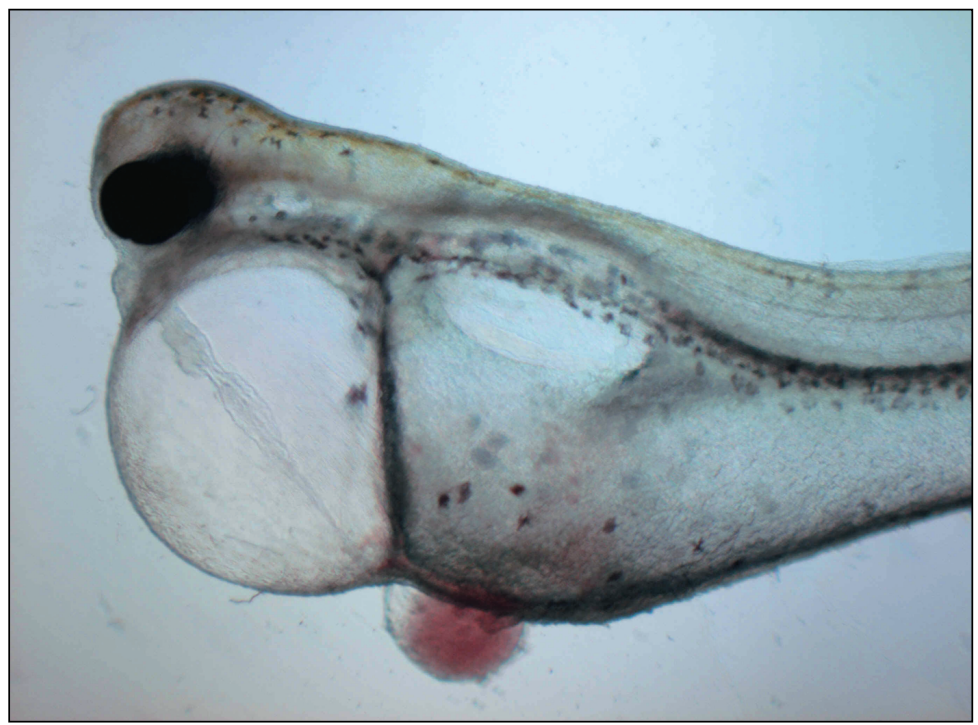

Fig. 4. Embryo (120 h old) exposed to the action of $\mathrm{K}_{2} \mathrm{Cr}_{2} \mathrm{O}_{7}$ at the concentration of $495 \mathrm{mg} \cdot \mathrm{l}^{-1}$. Deformities of yolk sac and head, heart area oedema. Magnification $\times 20$

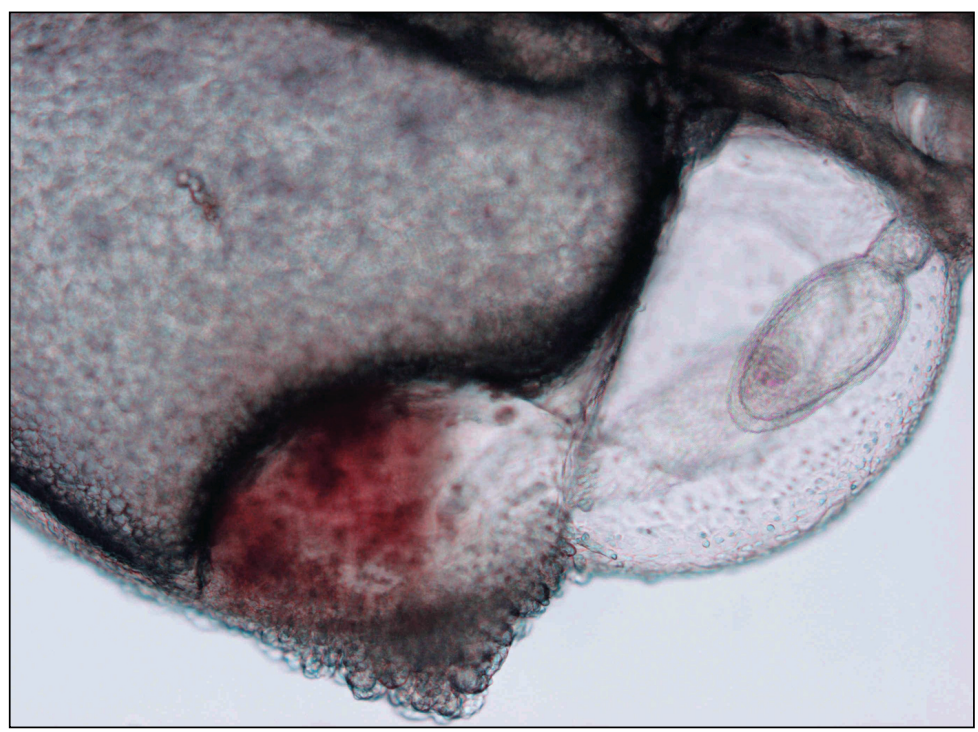

Fig. 5. Embryo (120 h old) exposed to the action of $\mathrm{K}_{2} \mathrm{Cr}_{2} \mathrm{O}_{7}$ at the concentration of $545 \mathrm{mg} \cdot \mathrm{l}^{-1}$. Heart area in detail. Magnification $\times 40$ 